\title{
Effect of Pre-Mating Water Deprivation on Ovarian Activity and on Reproductive Traits of Mature Barbarine Ewes during Summer Season
}

\author{
S. Khnissi, N. Lassoued, M. Rekik, and H. Ben Salem
}

\begin{abstract}
Barbarine ewes were used to study the effect of water deprivation on feed intake and reproductive traits. Animals were allocated to two groups of 30 animals each. Control ewes $(C)$ had free access to water while deprived ewes (D) were watered every 3 days during 8 weeks in mating period.Feed and water intake were recorded daily for each animal. Body weight was measured every week. Rectal temperature was also measured every week of the trial on the $1^{\text {st }}, 2^{\text {nd }}$ and the $3^{\text {rd }}$ day of water deprivation. Ovulation rate was determined by endoscopy 12 days after oestrus behaviour. Lambing rate and litter size were calculated. Body weight and feed intake were not affected $(P>0.05)$ by water deprivation. However water intake increase in deprived ewes $(P<0.01)$. Reproductive results showed that water deprivation did not affect significantly either the percentage of females in oestrus during the 3 days following ram introduction nor the return rate $(80 \%$ vs $90 \%$ and $13 \%$ vs $10 \%$ respectively for control and water deprivation groups). Moreover ovulation rate, fertility and litter size were similar for both groups $(110 \%$ vs $130 \%, 93.3 \%$ vs $100 \%$ and $103 \%$ vs $123 \%$ respectively for control and water deprivation groups). These results indicate the wide adaptation of Barbarine sheep for water deprivation as indicated by the absence of significant negative effects on reproductive performances.
\end{abstract}

Index Terms-Ewe, ovarian activity, reproductive traits, water deprivation.

\section{INTRODUCTION}

Prolonged dry season prevails in semi-arid regions werelivestock graze far away from watering sites. In such areas, water is scarce particularly during the long hot and dry periods of the year and animal in the field often face heat stress and dehydration.

Breeds of ruminants inhabiting hot arid and desert areas have acquired various adaptation mechanisms that aid them in withstanding one week with little or even no water, water deficiency is proved to affect animals' physiological homeostasis leading to loss of body weight, low reproductive rates and a decreased resistance to diseases [1]. Many studies show a close relation between water intake and feed consumption [2].

Manuscript received October 9, 2013; revised December 11, 2013. This work was supported by the Tunisian Ministry of Scientific Research and the tunisian Ministryn of Agriculture.

S. Khnissi, N. Lassoued, and H. Ben Salem are with INRA-Tunisie, Laboratoire des Productions Animales et Fourragères, Rue Hedi Karray, 2049,Ariana, Tunisia (e-mail: mleilsamia@live.fr, narlass@yahoo.fr, Bensalem.hichem@yahoo.com).

M. Rekik is with EcoleNationale de Médecine Vétérinaire, 2020, Sidi Thabet, Ariana, Tunisia (e-mail: rekik.mourad@iresa.agrinet.tn).
Several studies have demonstrated that heat stress can affect reproductive traits namely oestrus [3], ovulation rate [4] and embryonic mortality [5]. Nevertheless, the effect of water deprivation on ewe reproductive traits under hot conditions was not documented. The aim of this study is to investigate the effect of water deprivation during hot season, on oestrus, ovulation, and reproductive traits of mature Barbarine ewes in an attempt to further characterize the adaptive potential of this breed to dry areas [6].

\section{MATERIAL AND METHODS}

\section{A. Location and Animals}

The trial was carried out in the sheep research farm of BouRebiaà of the National Institute of Agricultural Research (INRAT). The station has a semi-arid climate, is located $25 \mathrm{~km}$ south of the town of Tunis $36^{\circ} 38^{\prime}{ }^{\circ} \mathrm{N}$ latitude, $10^{\circ} 07^{\prime}$ East longitude. Average annual rainfall is $350 \mathrm{~mm}$ and represents the mean of 30 years.During the experimental period, the ambient temperature averaged $38^{\circ}$ $\mathrm{C}\left(35^{\circ} \mathrm{C}\right.$ min $\left.-42^{\circ} \mathrm{C} \max \right) .60$ adult ewes of the Barbarine breed were selected from the farm flock. Prior to the experiment, the animals were reared under similar conditions and were kept outside throughout the day.

\section{B. Experimental Protocol}

In early July,the animals were divided into 2 groups balanced for live weight and age. They were placed in individual boxes inside a barn, well ventilated and were continuously exposed to natural daylight. Animals were subjected to one of two treatments, treatment D (deprived) receiving wateronce every three days and Treatment $\mathrm{C}$ (control) receiving water daily.Ewes had access to tap water in the morning in buckets of 151 capacity. Each of the 60 ewes was fed on a daily basis a diet composed of a mixture of straw $(1 \mathrm{~kg})$ and barley grains $(0.4 \mathrm{~kg})$ that was offered into 2 equal meals (at 08:00 and 19:00 h). The experiment lasted 32 days before and 28 days after introduction of rams. Therefore D animals were subjected to 8 successive cycles of water deprivation (3 consecutive days) and access to water ( 1 day) before male introduction. They were subjected to an adaptation period during which water deprivation was first imposed for 1 day, then for 2 days and thereafter for 3 consecutive days.

\section{Measurements}

Daily feed and water intake were determined throughout the experiment for 10 ewes of each groups. Live weight was recorded every week before the distribution of the meal. Rectal temperature was measured every week of the trial on 
the $1^{\text {st }}, 2^{\text {nd }}$ and the $3^{\text {rd }}$ day of water deprivation using digital thermometers.

For the homogeneous reproductive cycles, Fluorogestone acetate sponges were used to synchronise and control estrous cycles. At sponges' withdrawal, teaser rams of the Barbarine breed were introduced to the ewes at a ratio of 1 ram for every 10 ewes. Sheep demonstrating oestrus were naturally mated to rams. The oestrous response, date of lambing and number of lambs born were recorded

Ovarian activity, assessed by the presence of corpora lutea and ovulation rate, was determined by endoscopy [7].

\section{Statistical Analysis}

The data obtained are presented as (means \pm S.E). The statistical analysis was performed according to MIXED models procedure [8]. Source of variation included treatment with water deprivation and measurement time. The random variable was ewes within treatment. Comparisons of the proportions of ewes in reproductive traits were carried out using an X2 test

\section{RESULTS}

\section{A. Food and Water Intake}

The daily feed intake was not affected $(P>0.05)$ by the treatment (Fig. 1). In fact, control and water deprivation ewes consumed respectively $868.491 \pm 15.402 \mathrm{~g}$ and $852.804 \pm 15.402 \mathrm{~g}$ of dry mater. Water consumption during the first hour of re-hydration was significantly $(p<0.01)$ higher than that of controls or that consumed during hydration day. Indeed, in response to lack of water, water deprivation ewes increased their water intake until 10.983 \pm 0.929 lagainstan average of $6.676 \pm 0.9291$ in the control ewes (Fig. 2).

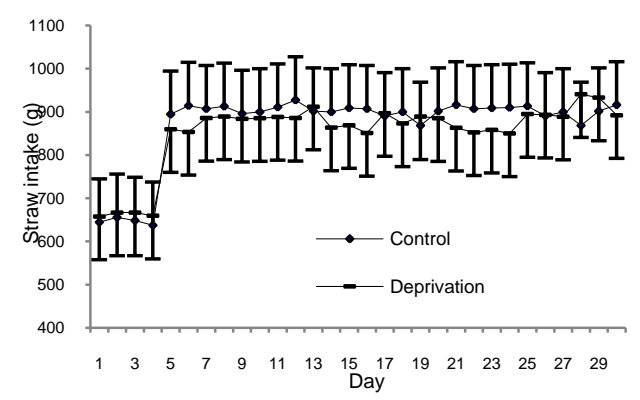

Fig. 1. Mean $( \pm \mathrm{SE})$ daily feed intake $(\mathrm{g})$ of control and water deprivation ewes.

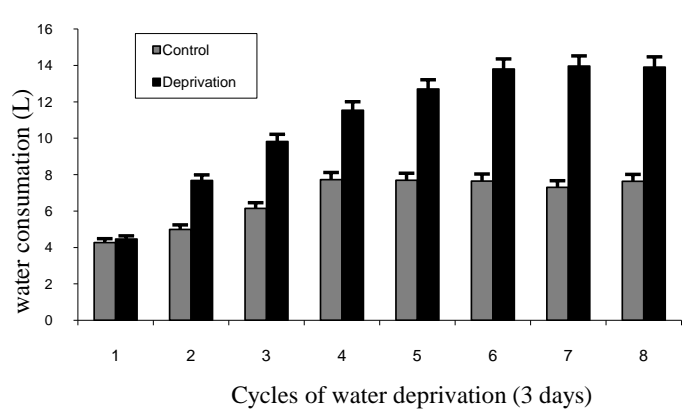

Fig. 2. Mean $( \pm$ SE) of water intake in the rehydration day of each cycle of the trial on $\mathrm{C}$ and $\mathrm{D}$ ewes.

\section{B. Live Body Weight}

The evolution of thebody weightof the eweswas similarin both groupsin the first twoweeks (5 cycles of water deprivation) of the experiment (Fig. 3). It was only afterthree weeks principally in the $6^{\text {th }}$ cycle of water deprivation wherethere was asignificant difference $(p<0.05)$ in body weightbetween groups.

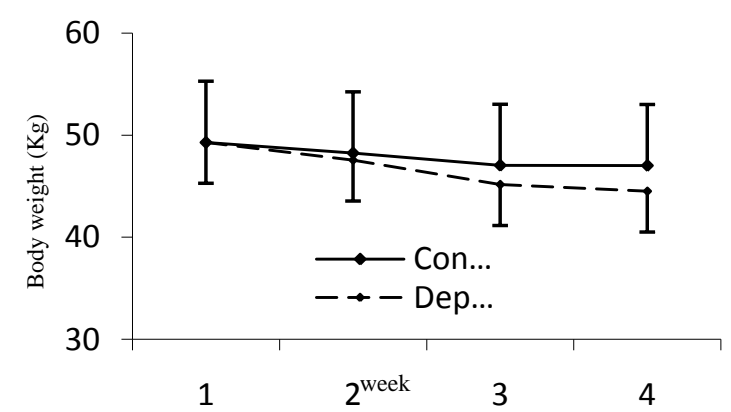

Fig. 3. Effect of water deprivation on the evolution of live weight of ewes in both groups during the pre mating period.

\section{Rectal Temperature}

Rectal temperature increased $(p<0.05)$ in ewes of the water deprivation group $39.32 \pm 0.01{ }^{\circ} \mathrm{Cas}$ compared with control ones $39.03 \pm 0.01{ }^{\circ} \mathrm{C}$ (Table I).

TABLE I: MEANS ( \pm S.E.M.), MinIMUM AND MAXIMUM VALUES OF RECTAL TEMPERATURE $\left({ }^{\circ} \mathrm{C}\right)$ OF CONTROL AND WATER DEPRIVED EWES

\begin{tabular}{|l|l|l|l|}
\hline Parameters & \multicolumn{2}{|l|}{ Treatment } & $P$ \\
\hline & $\begin{array}{l}\text { (C) Daily } \\
\text { watering }\end{array}$ & $\begin{array}{l}\text { (D) Once per } \\
\text { 3 days } \\
\text { watering }\end{array}$ & \\
\hline Average Tr & $39.035 \pm 0.015$ & $39.325 \pm 0.015$ & $<0.001$ \\
\hline Minimum & 38.7 & 38.9 & \\
\hline Maximum & 39.4 & 39.9 & \\
\hline
\end{tabular}

Tr: rectal temperature

D. Oestrus, Ovulation Rate, Fertility, Litter Size and Embryonic Mortality

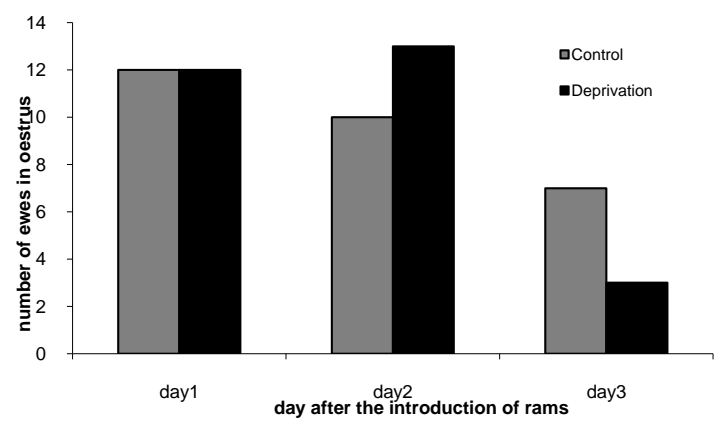

Fig. 4. The effect of water deprivation stress on the distribution of oestrus behaviour in the 3 days after the introduction of rams.

The percent of ewes that showed oestrus behaviour was shown in table II. According to treatment, $89 \%$ of deprived ewesagainst $76 \%$ showed oestrous behaviour in the first 2 days after the introduction of rams (Fig. 4), but this difference between groups was not statistically significant $(P>0.05)$.In the other hand the percentage of return $t$ oestrus 
is similar between the groups. (13\% vs $10 \%$ in C and D ewes respectively). The effect of water deprivation on ovulation was presented in Table III. Ovulation rate was $130 \%$ in D group vs $110 \%$ in $\mathrm{C}$ group and the number of double ovulation was respectively 9 vs $3(P>0.05)$.

Although deprived ewes exhibited improved lambing rates and litter size as compared with the control, this did not attain significance. Fertility was $100 \%$ vs $93 \%$ respectively in water deprivation and control group. Similarly, litter size was $123 \%$ vs $103 \%$ (Table. IV).

TABLEII: THE EFFECT OF WATER DEPRIVATION ON THE OESTRUS BEHAVIOUR

\begin{tabular}{|l|l|l|l|}
\hline Parameters & \multicolumn{2}{|l|}{ Treatment } & $P$ \\
\hline & $\begin{array}{l}\text { (C) Daily } \\
\text { watering }\end{array}$ & $\begin{array}{l}\text { (D)Once per 3 } \\
\text { days watering }\end{array}$ & \\
\hline Estrus (\%) & 80 & 90 & $>0.05$ \\
\hline $\begin{array}{l}\text { Rate of return } \\
\text { of œstrus (\%) }\end{array}$ & 13 & 10 & $>0.05$ \\
\hline
\end{tabular}

TABLE III: THE EFFECT OF WATER DEPRIVATION ON OVULATION RATE, NUMBER OF EWES WITH SINGLE OR DOUBLE OVULATIONS

\begin{tabular}{|l|l|l|l|}
\hline Parameters & \multicolumn{2}{|l|}{ Treatment } & $P$ \\
\hline & $\begin{array}{l}\text { Daily } \\
\text { watering (C) }\end{array}$ & $\begin{array}{l}\text { Once per 3 } \\
\text { days watering } \\
\text { (D) }\end{array}$ & \\
\hline Single ovulation & 27 & 21 & $>0.05$ \\
\hline Double ovulations & 3 & 9 & $>0.05$ \\
\hline Ovulation rate (\%) & 110 & 130 & $>0.05$ \\
\hline
\end{tabular}

TABLE IV: THE EFFECT OF WATER DEPRIVATION ON FERTILITY, LITTER SIZE AND EMBRYONIC MORTALITY

\begin{tabular}{|l|l|l|l|}
\hline Parameters & \multicolumn{2}{|l|}{ Treatment } & $P$ \\
\hline & $\begin{array}{l}\text { (C) Daily } \\
\text { watering }\end{array}$ & $\begin{array}{l}\text { (D) Once per 3 } \\
\text { days watering }\end{array}$ & \\
\hline Fertility (\%) & 93.33 & 100 & $>0.05$ \\
\hline Litter size (\%) & 103 & 123 & $>0.05$ \\
\hline $\begin{array}{l}\text { Embryonic } \\
\text { mortality (\%) }\end{array}$ & 3 & 5 & $>0.05$ \\
\hline
\end{tabular}

\section{DISCUSSION}

Climate change is affecting more and more water reserves especially in arid zones where unavailability of water in addition to high temperatures adversely affects her productivity in different levels. Barbarine breed is known by their attitude of adaptation to dry areas conditions.Waterdeprived ewes drank much more at each drinking time that control ewes. Our results agree with previous work [9]. The rumen is known to be a water reservoir that can store a large volume of water taken in at the end of dehydration period. In fact, 3 days of water deprivation can stimulated more water consumption in order to compensate for the high water deficiency caused by water losses. Studies on dehydrated sheep have shown that they were able to drink up to $23 \%$ of their dehydrated body weights [10]. This depends on the degree of body weight loss as well as the volume of the rumen, which could accommodate the volume of water ingested on rehydration.

Dehydration tolerance can be assessed essentially by the rate of body weight changes when water is scarce. During the trial, water deprivation causeda fall in body weight that began from the third week of treatment andcontinued till the end of deprivation period. This result was obtained without any drop of feed intake. However, most of previous works showed that feed consumption is strongly related to water intake [2], where sheep reduced their voluntary feed intake under 3-4 days intermittent watering regime [1], Specially when it is associated with heat stress [11]. In such cases, it is difficult to differentiate if loss ob body weight reflects changes in feed intake or changes in body water. Many authors showed that most of the live weight losses during dehydration were accounted for body water loss in small ruminants [12] result of a cortisol induced diuresis in stressed animals by water scarce [12].

Another consequence of dehydration is thermoregulation. In our work, rectal temperature value of the water-deprived ewes remained above that of the control ones. This is agree with previous works where temporary hyperthermia is often reported in dehydrated sheep [13]. Hyperthemia is one of mechanisms that allow animals to avoid excessive water expenditure during the hot part of the dayespecially as our study was conducted during the warmer months of the year. On the other side, authors reported that sheep are thermostable even during dehydration [14].

To our knowledge, studies on the effect of water deprivation on reproductive traits in sheep are very scarce. However, the effects of stressors like nutrition and ambient temperature on reproductive activity are reported in sheep [15].

Estrus behaviour in sheep is a part of a continuum of interaction between the sexes. The incidence of oestrus and receptivity of ewes are important factors that seem to be especially sensitive to stress [15]. However, in our study we didn't show that water deprivation affects significantly oestrus, despite that it seems that the number of water deprivation ewes come in heat is higher than in the control group.

The other reproductive parameters that reported in this study didn't show any significant differences between groups. However, ovulation rate, fertility and liter size were slightly higher in water deprived ewes than in the control ones. Despite this result was not statistically significant, it should be taken into consideration. Further studies are needed to deepen this effect since some authors reported a variation of some metabolites in serum that could explain a difference like increase in serum protein [13] due to the decreased blood volume.

\section{CONCLUSION}

This study showed that it is possible to conduct a mating during the hot season withonce per 3 days watering regime, without affecting reproductive traits in Barbarine ewes. Water economy appears to be important under the studied water limitation that demonstrates the adaptation of Barbarine. 


\section{ACKNOWLEDGMENT}

This work was supported by the Tunisian Ministry of Scientific Research and the tunisian Ministryn of Agriculture

\section{REFERENCES}

[1] L. Jaber, M. Chedid, and S. Hamadeh, Water Stress in Small Ruminants in «Responses of organisms to water stress, 1st ed. Şener Akıncı, Croatia, 2013, ch. 6, pp. 115-150.

[2] L. S. Jaber, N. Hanna, E. K. Barbour, M. A. Said, N. Rawda, M. Chedid, and S. K. Hamadeh, "Fat mobilization in water restricted Awassi ewes supplemented with vitamin C," Journal of Arid Environments, vol. 75, pp. 625-628, 2011.

[3] S. Casu, P. Cappai, and S. Naitona, "Effects of high temperature on reproduction in small ruminants,"Animal Husbandry in Warm Climates, EAAP Publication, no. 55, pp. 103-111, 1991.

[4] M. M. Mokhtar, H. T. Abdel-Bary, and A. M. El-Sharabasi, "Seasonal variation in the fertility of crossbred ewes," Egyptian J. of Anim Prod, vol. 28, pp. 31-38, 1991.

[5] T. R. H. Regnault, R. J. Orbus, B. de-Vrijer, B. M. L. Davidsen, H. L. Galan, R. B. Wilkening, and R. V. Anthony, "Placental expression of VEGF, PIGF and their receptors in a model of placental insufficiency-intrauterine growth restriction (PI-IUGR)," Placenta, vol. 23, pp. 132-144, 2002.

[6] H. B. Salem, N. Lassoued, and M. Rekik, "On the merits of the fattailed Barbarine sheep raised in different production systems in Tunisia: Digestive, productive and reproductive particularities, Trop. Anim," Health. Prod. , E Pub, vol. 43, no. 7, pp. 1357-1370, 2011

[7] J. Thimonier and P. Mauleon, "Variations saisonnières du comportement des activités ovarienne et hypophysaire chez les ovins," Ann. Biol. Anim. Biochem. Biophys., vol. 9, pp. 233-250, 1969.

[8] SAS, Statistical Analysis System, N.C., USA Institute Inc., 2005.

[9] A. Aganga, N. N. Umunna, E. O. Oyedipe, I. P. N. Okoh, and A. O. Aduku, "Response to water deprivation by yankasa ewes under different physiological states," Small Ruminant Research, vol. 109, pp. 115-109, 1990.

[10] S. Laden, L. Nehmadi, and R. Yagil, "Dehydration tolerance in Awassi fat-tailed sheep," Can. J. Zool., vol. 65, pp. 363-367, 1987.

[11] G. M. O. Maloiy, T. I. Kanui, P. K. Towett, S. N. Wambugu, J. O. Miaron, and M. M. Wanyoike, "Effects of dehydration and heat stress on food intake and dry matter digestibility in East African ruminants," Comparative Biochemistry and Physiology, vol. A, no.151, pp. 185190, 2008.

[12] A. J. Parker, G. P. Hamlin, C. J. Coleman, and L. A. Fitzpatrick, "Dehydration in stressed ruminantsmay be the result of a cortisol induced diuresis," Journal of Animal Sciences, vol. 81, pp. 512-519, 2003.

[13] A. M. Ghanem, E. K. Barbour, S. K. Hamadeh, L. S. Jaber, M. A. Said, "Physiological and chemical responses in water-deprived
Awassi ewes treated with vitamin C," J. of Arid Environments, vol. 72, pp. 141-149, 2008

[14] A. A. Degen, "Fat-tailed Awassi and German Mutton Merino Sheep under semi-arid conditions," Journal of Agricultural Science, Camb., vol. 88, pp. 699-704, 1977.

[15] H. Dobson, C. Fergani, J. E. Routly, and R. F. Smith, "Effects of stress on reproduction in ewes," Animal Reproduction Science, vol. 130, pp. 135-140, 2012.

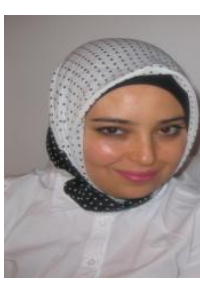

Samia Khnissi was born at Gafsa, Tunisia on December 19, 1979. In 1999, she got the Bachelor experimental sciences in technical school, Gafsa, Tunisia. On 2004, she got Master's degree in Life Sciences, Biotechnology Specialty in faculty of Sciences, Tunis, Tunisia. On 2007, she got Master in Therapeutically Active Natural Substances in faculty of Sciences, Bizerte, Tunisia. Actually she is a PhD student in reproductive physiology.

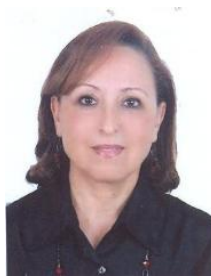

Narjess Lassoued was born in Nabeul, Tunisia on July 31, 1956. She did her university studies in Natural Sciences at the Faculty of Sciences of Tunis, Tunisia. She got her degree in 1979. Then, she continued on Ph.D. in Nutrition that she obtained in October 1982 at the University of "Pierre et Marie Curie" in Paris 6 (France) and after she completed a second $\mathrm{PhD}$ in physiology in 1998 at the Faculty of Sciences of Tunis (Tunisia). The title of the last Ph.D is: Induction of ovulation by 'male effect' in seasonal anoestrus Barbarine ewes. Mechanisms involved in the existence of the short induced cycle.

Narjess was recruited to INRA Tunisia since 1983 as a researcher in Sheep and Goats Reproduction \& Management. Since she has worked in the management of small ruminants and especially in the field of reproductive physiology. The main focus of research has been the characterization of indigenous breeds in terms of reproductive, the interactions between nutrition and reproduction, and adaptation of animals to arid and semi-arid conditions. In recent years, she focuses on environmental factors, temperature and water in quantity and quality and its effect on the different phases of reproduction in small ruminants. She has published widely in these fields about 40 scientific papers and book chapters. She is responsible for many programs of research and researchdevelopment. During her carrier, she has been the head of laboratory of sheep and goat research during 6 years since 1991 .

Dr. Lassoued is the president of National Committee of Evaluation and Programming Research in the field of Animal Production. She is a member of many committees of scientific evaluation. She is a membership of association of agricultural researchers in Tunisia. She received a Price for the exemplary worker awarded by the President of the Republic on the feast day of work on 1999. 